\title{
階段状水路における空気混入流特性 AERATED FLOW CHARACTERISTICS ON STEPPED CHANNELS
}

\author{
高橋正行 1 ・安田陽 ${ }^{2} \cdot$ 大津岩夫 $^{3}$ \\ Masayuki TAKAHASHI, Youichi YASUDA, and Iwao OHTSU \\ 1正会員 博（工） 日本大学専任講師 理工学部土木工学科（干101-8308 東京都千代田区神田駿河台1-8） \\ 2正会員 博(工) 日本大学教授 理工学部土木工学科（干101-8308 東京都千代田区神田駿河台1-8) \\ 3フェロー会員 工博 日本大学教授 理工学部土木工学科（广101-8308 東京都千代田区神田駿河台1-8）
}

\begin{abstract}
Stepped channels are effective for dissipating the energy of supercritical flow that occurs at steep channels. Generally, the flow conditions in stepped channels have been classified into skimming flow, transition flow, and nappe flow. Also, stepped channel flows have been characterized as aerated flows. For design purposes, it is important to predict the aerated flow velocity, the air-concentration, and the energy head of aerated flows in skimming, transition, and nappe flows.

In this paper, aerated flow characteristics of skimming, transition, and nappe flows have been investigated for a wide range of relative step height $S / d_{c}$ under a given channel slope $\theta=19^{\circ}$. It was found that the velocity and air-concentration profiles characterize each flow condition. The energy head of aerated flows $E$ in skimming, transition, and nappe flows has been determined from the air-concentration $C$ and the aerated flow velocity $u$.
\end{abstract}

Key Words : Stepped channel, aerated flow, air-concentration, velocity, energy head, skimming flow, transition flow, nappe flow

\section{1. まえがき}

堰やダム，急傾斜地に設置された水路を流下する高 速流を傾斜面上で減勢させる方法として階段状水路は 有効である ${ }^{1), 2)}$.

階段状水路において観察される流況はskimming flow, transition flow, およびnappe flowに分類されている1),3)

（図-1）.それらの流況分類は流況の観察に基づいて 行われているが，各流況に対応した内部特性の変化は 示されていない. また, 階段状水路での流れは空気混 入流 (aerated flow) となるが, 空気混入流の流速やエネ ルギーについては不明な点が多く, skimming flowの場 合はBoes and Hagaer ${ }^{4)}$, transition flowの場合はChanson and Toombes ${ }^{5}$ やEL-Kamash et al. ${ }^{6}$ による検討があるもの の，限定された範囲での実験結果が提示されているに すぎない.

これまでに, Ohtsu et al. ${ }^{2}$ (はskimming flowの抵抗係数に ついて広範囲な水路傾斜角度 $\theta$ おび相対ステップ高さ $S / d_{c}\left[d_{c}=\left(q_{w}{ }^{2} / g\right)^{1 / 3} ; d_{c}\right.$ : 限界水深, $g$ : 重力加速度, $S$ : ステップ高さ, $q_{w}$ : 水の単位幅流量 $]$ のとで検討 し，与えられたS/d $/ d_{c}$ 対して $\theta=19^{\circ}$ のときに抵抗係数が (a)

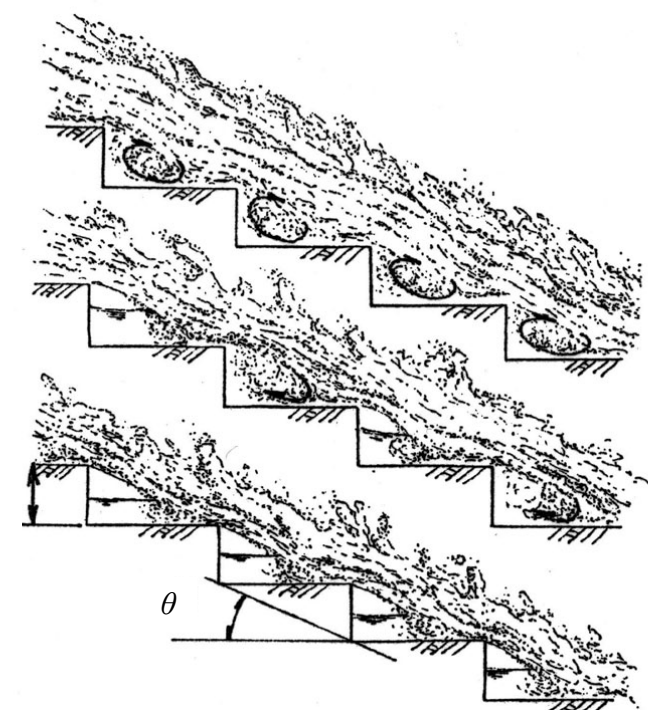

図-1 階段状水路に形成される流況

(a) skimming flow; (b) transition flow; (c)nappe flow 最大となることを示した. これは，ステップエッジ直上 流における主流の衝突領域が流水抵抗に影響し，この影 響が $\theta=19^{\circ}$ で最大となるためと推論した ${ }^{2)}$. また, skimming flowにおける空気混入流のエネルギ一評価法を 提案2),7) した.

ここでは, skimming flowの範囲では抵抗係数が最大と 


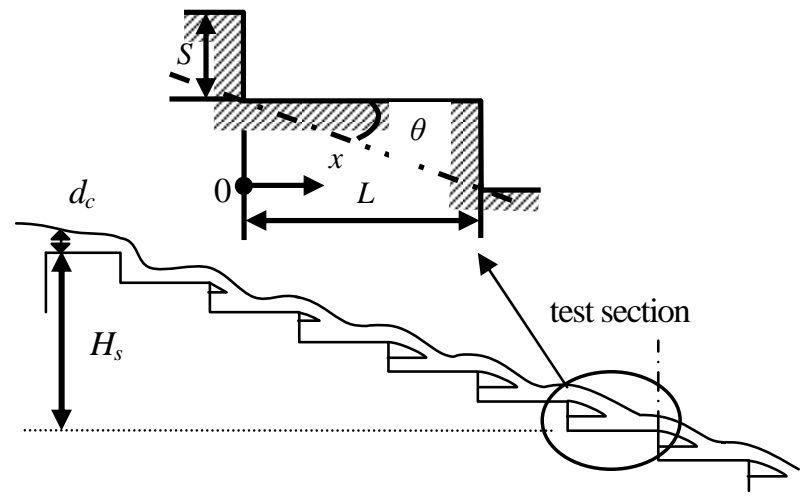

図-2 定義図

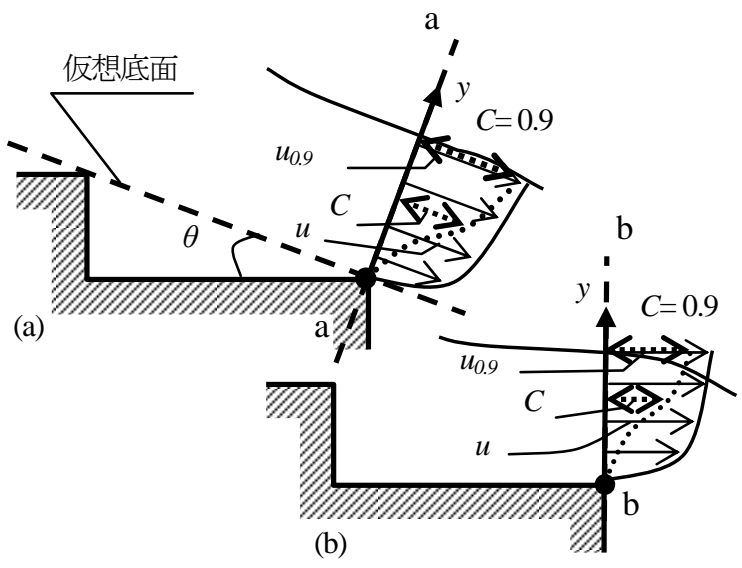

図-3代表断面の定義図

なる水路傾斜角度 $\theta=19^{\circ}$ を対象に，広範囲な $S / d_{c}$ に対し てskimming flow, transition flow, およびnappe flowの空 気混入率 $[$ 空気混入率 $=($ 空気の体積 $) /($ 水の体積十空気 の体積)］と流速を測定し各流況の内部特性を示した. その結果, 空気混入率と流速の特性から各流況を特徵づ けることができた．また，空気混入流の断面平均流速を 示すことができた．さらに，従来提案したskimming flow の空気混入流のエネルギー評価法2),7) transition flow nappe flowにまで拡張し, 各流況の空気混入流のエネル ギー水頭Eを明らかにした。また，空気混入流のエネル ギ一水頭 $E$ と空気混入流の空気を除いて水のみに換算し た水深として定義されるclear water depth $d_{w}$ を用いて求め られるエネルギー水頭 $E_{w}$ との対応を示した.

\section{2. 実験}

水路傾斜角度 $\theta=19^{\circ}$ の階段状水路における空気混入 流の内部特性を明らかにするため， $0.30 \leqq S / d_{c} \leqq 5.5 ， 11$ $\leqq H_{s} / d_{c} \leqq 78 ，\left[H_{s}\right.$ : 測定断面までの落差（図-2参照）] の広範囲な条件のもとで実験を行った。 空気混入率 $C$ と 流速Uはステップエッジ近くの断面 $(x / L=0.97$, 図-2) で 2点電極型ボイド率計 $\left.{ }^{8}\right)$ を用いて計測した(プローブ先端 直径 $\phi=0.0025 \mathrm{~mm}$, 測定時間 $20 \mathrm{sec}$, 測定間隔 $50 \mu \mathrm{sec}$ ). また，空気混入率 $C$ と流速 $u$ は，平衡状態（各ステップ で同じ流況が繰り返されている状態）の流れで計測を 行った.さらに，平行流とみなせる断面で測定するため，

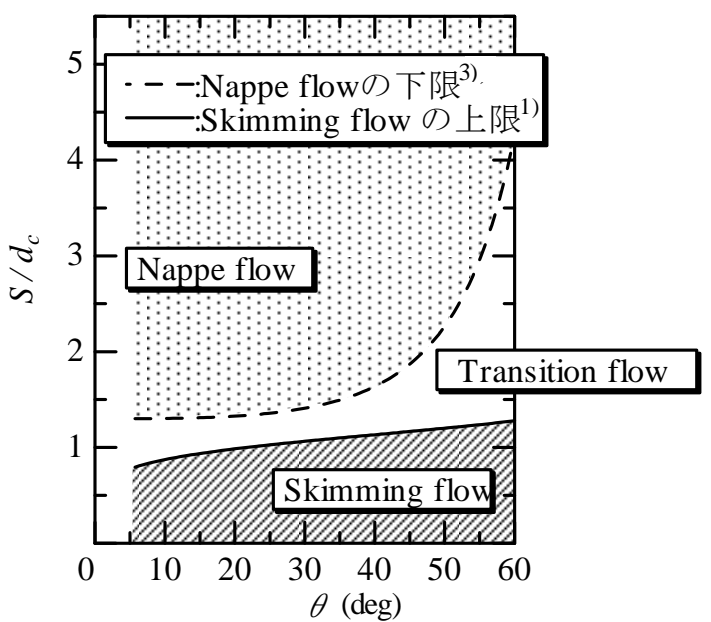

図-4 流況形成領域図

skimming flowの場合は図-3(a)のa-a断面で測定を行い, transition flowおよびnappe flowの場合は図-3(b)のb-b断面 で測定を行った。

\section{3. 流況}

階段状水路における流れの流況は相対ステップ高さ $S / d_{c}$ および水路傾斜角度 $\theta$ によって変化する ${ }^{1)}$ ，与えられ た $\theta$ に対して，S/d $/$ を大きくすると，図-1に示されるよう に, skimming flow, transition flow, およびnappe flowの 流況が形成される.これらは流況の観察に基いて区分さ れている. skimming flowは各ステップ隅角部で常に渦が 形成される流況であり, nappe flowは各ステップ隅角部 において常にエアーポケットの形成される流況である. また, transition flowはいくつかのステップ隅角部では渦 が形成され，その他のステップ隅角部ではエアーポケッ トが形成されている。この流況はOhtsu and Yasudaに よって初めて定義された流況1),10)である. 各流況の形成 領域を図-4に示す.

\section{4. 空気混入率分布}

平衡状態におけるskimming flowにおいて，高橋ら $R_{e} \geqq 3.0 \times 10^{4}\left[R_{e}\right.$ ：レイノルズ数 $\left(R_{e}=q_{\mathrm{w}} / \nu_{\mathrm{w}} ; v_{\mathrm{w}}=\right.$ 水の動粘 性係数)]の範囲では空気混入率 $C$ は $R_{e}$ の影響を受けない ことを明らかにし，Cは次の関係で整理されることを示 している.

$$
C=F\left(\frac{y}{y_{0.9}}, \frac{S}{d_{c}}, \theta\right)
$$

ここに，yは座標（図-3参照）， $y_{0.9}$ はaerated flow depthで あり $C=0.9$ となる位置のyである. transition flowおよび nappe flowにおいても, 空気混入率は(1)式の関係で示さ 


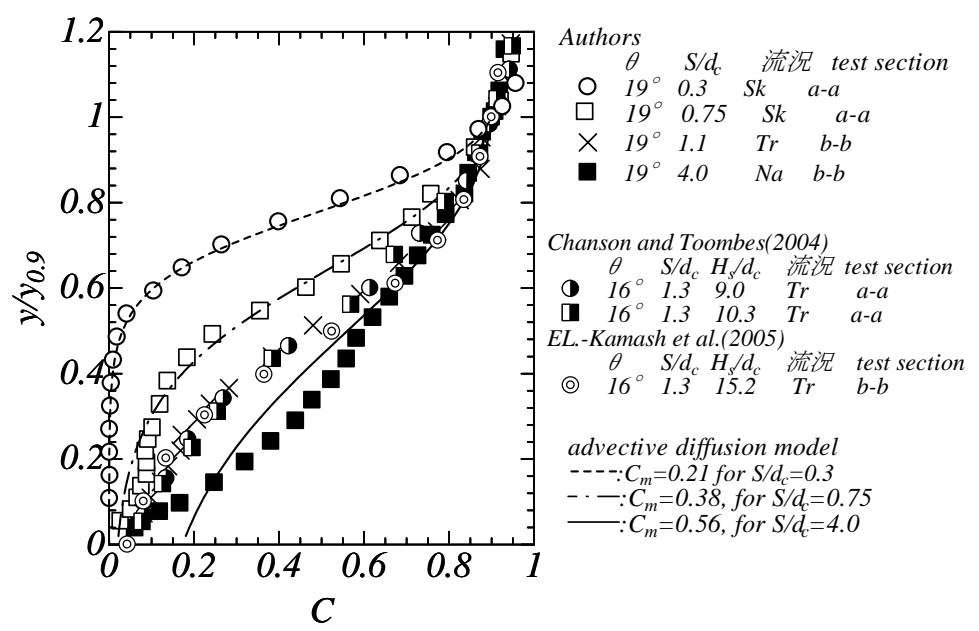

Sk: Skimming flow, Tr: Transition flow, Na: Nappe flow 図-5 空気混入率分布

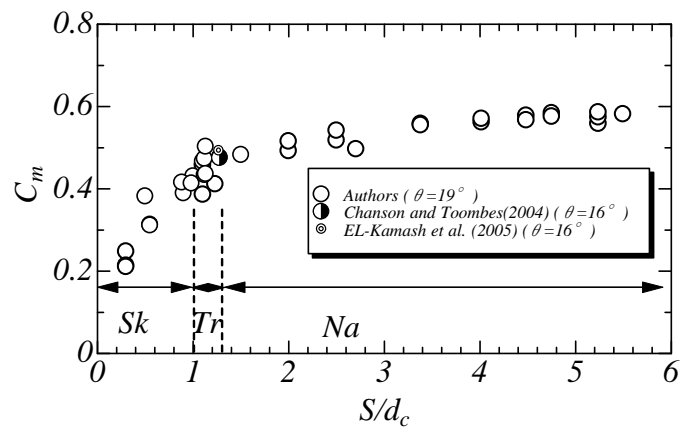

Sk:Skimming flow,Tr:Transition flow, Na:Nappe flow

図-6 断面平均空気混入率 $C_{m}$ $S / d_{c}$ の関係

\section{れるものと考えられる.}

(1)式の関係でskimming flow, transition flow, および nappe flowの空気混入率Cの実験值を整理すると図-5が得 られる. skimming flow, transition flow，および $S / d_{c}<3.0$ のnappe flowの場合, 与えられたy/ $/ y_{0.9}$ に対して $S / d_{c}$ の増加 に伴いCの值も増加寸る. $3.0 \leqq S / d_{c} \leqq 5.5$ のnappe flowの場 合, 空気混入率分布はS $/ d_{c}$ の影響を受けず, $y / y_{0.9}$ のみで 決まる.なお, transition flowにおけるEL-Kamash et al.の 実験值6) $\left(\theta=16^{\circ} ， S / d_{c}=1.3 ）\right.$ は図-3(a)のa-a断面で測定 され, Chanson and Toombes $の$ 実験值 ${ }^{5)}\left(\theta=16^{\circ}\right.$, $\left.S / d_{c}=1.3\right)$ は図-3(b)のb-b断面で測定されたものであり両 者はほぼ等しい值を示している（図-5）。すなわち, transition flowの空気混入率分布に対寸る測定断面の違い は認められない.

Chansonによって提案されている気泡の拡散モデル ${ }^{11)}$ より求めた空気混入率の分布を図-5に示寸．図-5に示さ れるように, skimming flowの空気混入率分布は気泡の拡 散モデルによって近似できる. 一方, nappe flowの空気 混入率分布はこのモデルでは近似できない.

次式で定義される断面平均空気混入率 $C_{m}$ の值を図-6に 示寸.

$$
C_{m}=\frac{1}{y_{0.9}} \int_{0}^{y_{0.9}} C d y
$$

$\theta=19^{\circ}$ の場合, 平衡状態における断面平均空気混入率 $C_{m}$

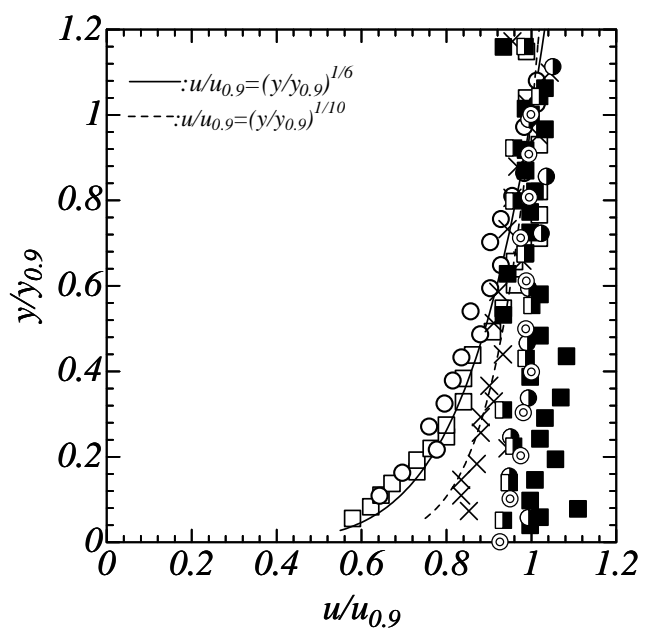

凡例は図ー5に同じ

図-7 流速分布

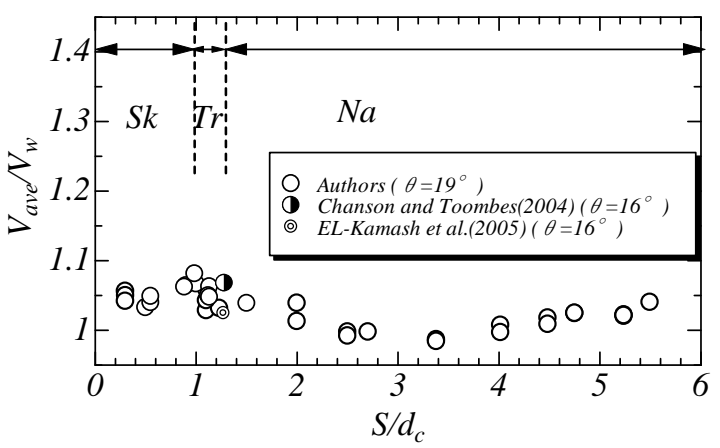

Sk:Skimming flow, Tr:Transition flow, Na:Nappe flow 図-8 $V_{a v e} / V_{w}$ $S / d_{c}$ の関係

の值は相対ステップ高さS/ $d_{c}$ の増加にともない大きくなる. $3.0<S / d_{c}<5.5$ のnappe flowの場合, $C_{m}$ の值は0.57に近づく.

\section{5. 流速分布}

平衡状態のskimming flow, transition flow, およびnappe flowにおいて, $R_{e} \geqq 3.0 \times 10^{4}$ の空気混入流の流速は次式 の関係で整理されるものと考えられる99.

$$
\frac{u}{u_{0.9}}=F\left(\frac{y}{y_{0.9}}, \frac{S}{d_{c}}, \theta\right)
$$

ここに， $u_{0.9}$ は $y_{0.9}$ の位置での流速である.

$u / u_{0.9}$ の実験值を(3)式の関係で整理すると図-7が得られ る. skimming flowとtransition flowの場合, 次式で示す $1 / N$ 乗則で流速分布が近似できる.

$$
\frac{u}{u_{0.9}}=\left(\frac{y}{y_{0.9}}\right)^{\frac{1}{N}}
$$

skimming flowの場合のNの值は6〜9であり, transition flow の場合のNの值は9〜11であった. なお, transition flowの 場合，空気混入率分布と同様に流速分布に対寸る測定断 面 [図-3(a), (b)] の違いは認められない (図-7参照) .

nappe flowの場合, 流速分布は一様分布となる傾向がある. これは，ナップが水平ステップ面上に衝突して形成される 
impact-region［図-13(c)参照の影響のためと考えられる. 空気混入流の断面平均流速 $V_{\text {ave }}$ を次式で定義する.

$$
V_{\text {ave }}=\frac{1}{y_{0.9}} \int_{0}^{y_{0.9}} u d y
$$

空気混入流の断面平均流速 $V_{a v e}$ とclear water depth $d_{w}$ から 求められる平均流速 $V_{w}\left(=q_{w} / d_{w}\right)$ との比 $V_{a v e} / V_{w}$ を図-8に示寸 ここに, clear water depth $d_{w}$ は空気混入流の空気を除いて 水のみに換算した水深として(6)式で定義され，Cの測定 值を用いて次式で求められる.

$$
d_{w}=\int_{0}^{y_{0.9}}(1-C) d y=\left(1-C_{m}\right) y_{0.9}
$$

なお，著者らの研究2), 12) によると $q_{w}, S, \theta か ゙$ 与えら ると， $d_{w}$ と $V_{w}$ は算定できる. また, 図一から $C_{m}$ を求め, 算定された $d_{w}$ と(6)式から aerated flow depth $y_{0.9}$ を算定でき る.これと測定值との誤差は土10\%以内であった.

従来 $V_{\text {ave }}$ については, 空気混入流の流速測定の困難さ から不明な状況であった。ここでは $V_{\text {ave }}$ が図-8のように 示され, $0.3 \leqq S / d_{c} \leqq 5.5 \odot$ skimming flow, transition flow, お よびnappe flowでは, $V_{\text {ave }} / V_{w}$ の值は1.01〜1.08であった. 安全側を考えると $V_{w}\left(=q_{w} / d_{w}\right)$ を知り，これを1.1倍する ことで空気混入流の断面平均流速 $V_{\text {ave }}$ を予測できる.

\section{6. 各流況のエネルギ一水頭}

skimming flowの場合, 空気混入流は仮想底面 [図3(a)］にほぼ平行となる. この場合のエネルギー評価法 はOhtsu et al. ${ }^{2)}$ )》によって提案されている.

transition flowの場合，エネルギー評価断面を図-3(a) のa-a断面に選んでも図-3(b) のb-b断面に選んでも空気 混入率と流速分布に違いは認められない（4.5.5参照）。 また，エネルギー評価断面としてa-a断面，b-b断面のど ちらを選んでもエネルギー算定結果はほぼ等しい. ここ ではエネルギー評価断面をb-b断面のように定める.

nappe flowの場合, 高速ビデオカメラによる流況観察 からステップエッジ近くの流れはステップ水平面と平行 であることが確認されたため，エネルギー評価断面を 図-3(b)のb-b断面のように定める.

transition flowとnappe flowにおけるステップ水平面上の 空気混入流のエネルギー水頭Eは次式で表示される.

$$
\begin{gathered}
E=\frac{\int_{0}^{y_{0.9}}[\rho g y+p] u d y}{\int_{0}^{y_{0.9}} \rho g u d y}+\frac{\int_{0}^{y_{0.9}}\left[\frac{1}{2} \rho u^{3}\right] d y}{\int_{0}^{y_{0.9}} \rho g u d y} \\
=\frac{\int_{0}^{y_{0.9}}\left[(1-C) \rho_{w} g y+\int_{y}^{y_{0.9}}(1-C) \rho_{w} g d y\right] u d y}{\int_{0}^{y_{0.9}}(1-C) \rho_{w} g u d y} \\
+\frac{\int_{0}^{y_{0.9}}\left[\frac{1}{2}(1-C) \rho_{w} u^{3}\right] d y}{\int_{0}^{y_{0.9}}(1-C) \rho_{w} g u d y}
\end{gathered}
$$

ここに，pは空気混入流中の圧力 $\left(p=\int_{y}^{y_{0.9}} \rho g d y\right)$ であり， $\rho$ は空気混入流の密度 $\left[\rho=(1-C) \rho_{w} ; \rho_{w}\right.$ は水の密度 $]$ であ る.

エネルギー水頭 $E$ をclear water depth $d_{w}$ および断面平均 流速 $V_{w}\left(=q_{w} / d_{w}\right)$ で表すと，(7)式は補正係数 $C_{p}$ および $C_{v}$ を 用いて次のように示される.

$$
E=C_{p} d_{w}+C_{v} \frac{V_{w}{ }^{2}}{2 g}
$$

(8)式中の補正係数 $C_{p}$ と $C_{v}$ はそれぞれ次のように示される.

$$
\begin{gathered}
C_{p}=\frac{\int_{0}^{y_{0,9}}\left[(1-C) y+\int_{y}^{y_{0.9}}(1-C) d y\right] u d y}{d_{w} \int_{0}^{y_{0,9}}(1-C) u d y} \\
=\frac{\int_{0}^{y_{0,9}}(\rho g y+p) u d y}{\int_{0}^{d_{w}}\left(\rho_{w} g y+p_{w}\right) V_{w} d y} \\
C_{v}=\frac{\int_{0}^{y_{0.9}}(1-C) u^{3} d y}{V_{w}{ }^{2} \int_{0}^{y_{09}}(1-C) u d y}=\frac{\int_{0}^{y_{0.9}} \frac{1}{2} \rho u^{2} u d y}{\rho_{w} q_{w} \frac{1}{2} V_{w}{ }^{2}}
\end{gathered}
$$

ここに， $p_{w}$ はclear waterの圧力として $\left(p_{w}=\int_{y}^{d_{w}} \rho_{w} g d y\right)$ とおく.

式(9)より， $C_{p}$ は断面を通過する空気混入流のポテンシャ ルエネルギーと圧力のなす仕事の和とclear water flowの それらの和の比と解釈される。 また(10)式より， $C_{v}$ は断 面を通過する空気混入流の運動エネルギーとclear water の運動エネルギーの比と解釈される.

$Y=y / y_{0.9}$ および $U=u / u_{0.9}$ を用いると， $C_{p}$ と $C_{v}$ は次式で 表示される.

$$
\begin{gathered}
C_{p}=\frac{\int_{0}^{1}\left[(1-C) Y+\int_{Y}^{1}(1-C) d Y\right] U d Y}{\left(1-\int_{0}^{1} C d Y\right) \int_{0}^{1}(1-C) U d Y} \\
C_{v}=\frac{\left(1-\int_{0}^{1} C d Y\right)^{2} \int_{0}^{1}(1-C) U^{3} d Y}{\left[\int_{0}^{1}(1-C) U d Y\right]^{3}}
\end{gathered}
$$

(11)式と(12)式から, 補正係数 $C_{p}$ と $C_{v}$ の值は空気混入流 の流速Uと空気混入率Cから求まる.

Skimming flowにおける仮想底面上の空気混入流 [図3(a)]のエネルギー水頭は次式で求められる2),7.

$$
E=C_{p} d_{w} \cos \theta+C_{v} \frac{V_{w}{ }^{2}}{2 g}
$$

ここに， $C_{p}$ と $C_{v}$ はそれぞれ(11)式と(12)式で与えられる. 水路傾斜角度 $\theta=19^{\circ}$ で各流況の平衡状態の場合の $C_{p}$ と

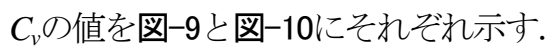

skimming flow とtransition flow $\left(0.3 \leqq S / d_{c} \leqq 1.3\right)$ の場合, $C_{v}$ の值は1.00から1.13となり, $S / d_{c}$ の増加に伴い $C_{v}$ の値は 


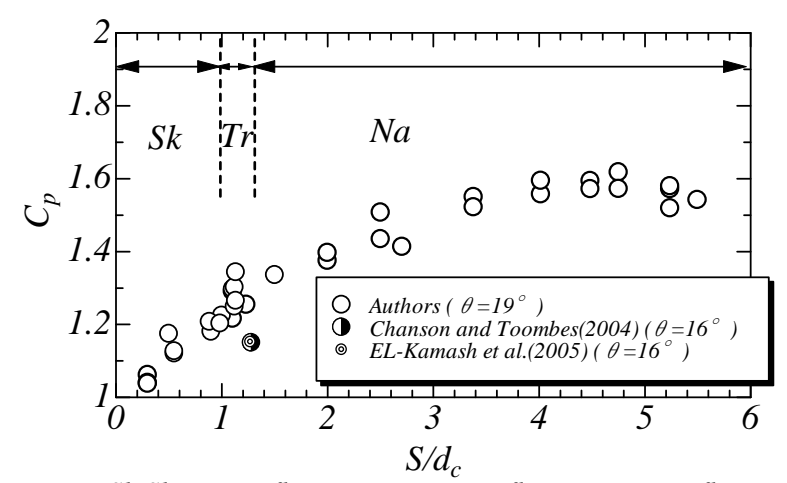

Sk:Skimming flow, Tr:Transition flow, Na:Nappe flow

図-9 補正係数 $C_{p}$ と $S / d_{c}$ との関係

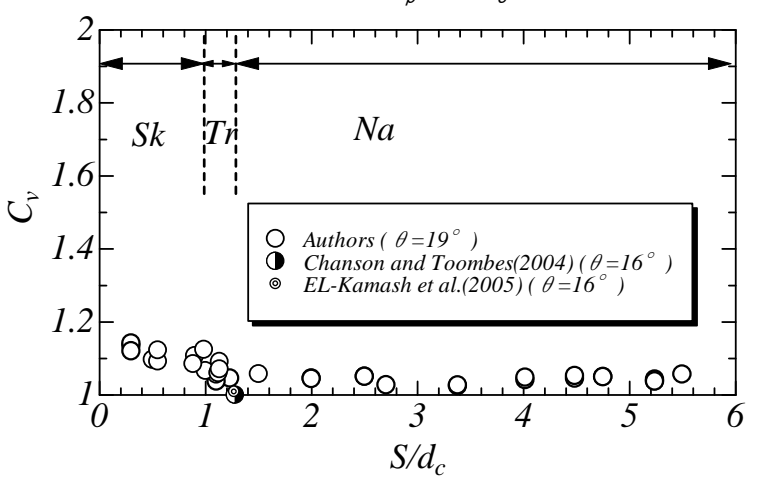

Sk:Skimming flow, Tr:Transition flow, Na:Nappe flow

図-10 補正係数 $C_{v}$ と $S / d_{c}$ との関係

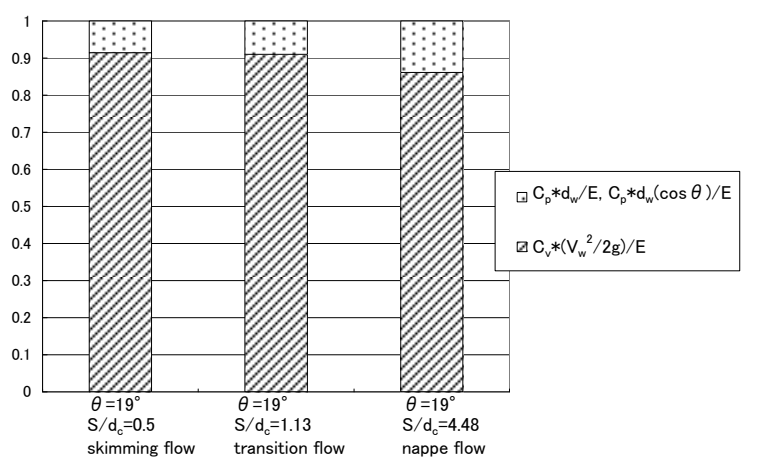

図-11 $E$ に対する速度水頭およびピエゾ水頭の割合

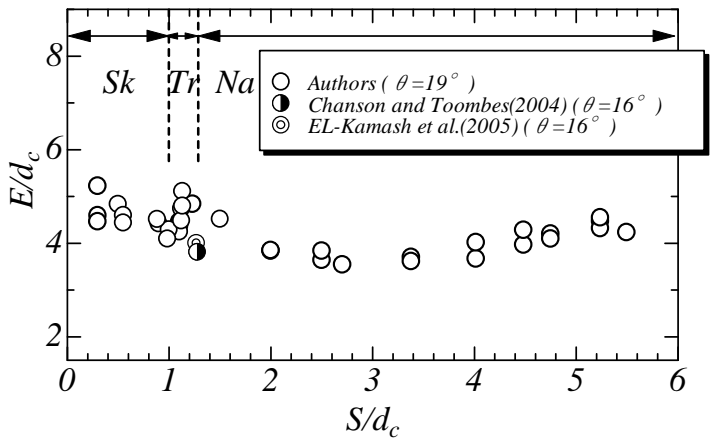

Sk:Skimming flow, Tr:Transition flow, Na:Nappe flow

図-12 $E / d_{c}$ とS/ $d_{c}$ との関係

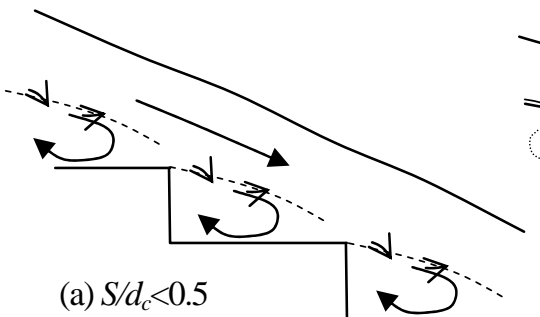

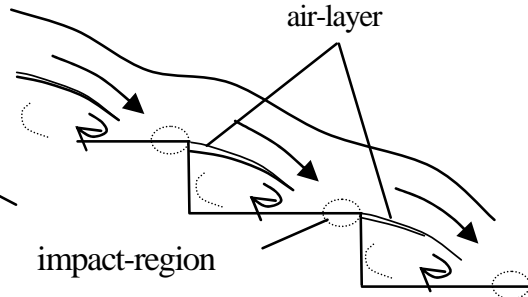

(b) $0.5 \leq S / d_{c} \leq 0.97$

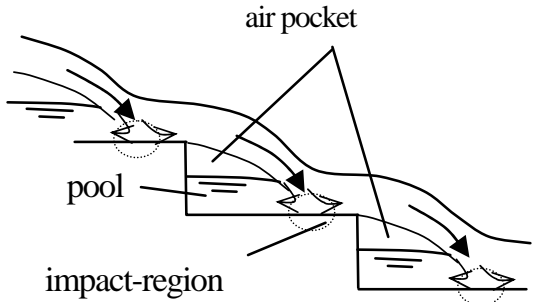

(c) $S / d_{c} \fallingdotseq 3$

図-13 air-layerと衝突領域の形成状況

わずかに小さくなる. nappe flow $\left(1.3 \leqq S / d_{c} \leqq 5.5\right)$ の場合, $C_{V}$ の值はほぼ一定值の1.05 となる。これは，測定断面で の u $_{0.9}$ の分布は一様分布（図-7）に近くなるためである. $C_{p}$ の值（図-9）は $0.3 \leqq S / d_{c} \leqq 3.5$ の場合 $S / d_{c}$ の増加に伴 い増加し， $3.5 \leqq S / d_{c} \leqq 5.5$ の場合ほぼ一定となっている.

これは, $3.5 \leqq S / d_{c} \leqq 5.5$ のnappe flowの場合, 空気混入率C の分布はS $/ d_{c}$ の影響を受けなくなったためである.

空気混入流中のエネルギー水頭 $E$ に対する $C_{p}$ の影響を 調べると， $C_{p}$ のEに対する影響は小さい. これは空気混 入流のエネルギーの $80 \%$ から $90 \%$ を速度水頭が占め, ピ エゾ水頭は $10 \%$ から $20 \%$ 程度しか占めていないためであ る (図-11参照) .

空気混入流のエネルギー水頭 $E / d_{c}$ を図-12に示す.

$0.3 \leqq S / d_{c}<0.5$ のskimming flowの場合, $S / d_{c}$ が小さくな るとE/d $d_{c}$ 值は大きくなっている，これは，主流と隅角 部内の渦との相互干渉およびステップエッジ付近の impact-regionの影響による流れの抵抗がS $/ d_{c}$ にって変化 するためと考えられる（図-13(a)参照）。

$0.50 \leqq S / d_{c} \leqq 0.97$ のkimming flowの場合, 各ステップ エッジ直下流で間欠的にair-layerが観察される. 寸なわ ち，主流とステップ隅角部内の流体との間の相互干渉は 小さくなり，流れの抵抗に対するimpact-regionの影響が 大きくなる. このため, $S / d_{c} に よ る E / d_{c}$ の変化は小さく なったものと考えられる (図-13(b)) .

transition flowの場合, 各ステップエッジ下流ではairlayerもしくはエアーポケットが形成されるため, $E / d_{c}$ の 值にばらつきが生じたものと考えられる.

$1.3<S / d_{c} \leqq 4.0$ のnappe flowになると全てのステップ隅 角部でエアーポケットが形成される (図-13(c)) 。この 範囲では主流とステップ隅角部内の流体との間で流れの 相互干渉は小さく，エネルギー損失に対する衝突領域 [impact-region(図-13(c))］の影響が大きくなるため, $S / d_{c}$ にる $E / d_{c}$ の変化が小さくなったのであろうと考え られる. 


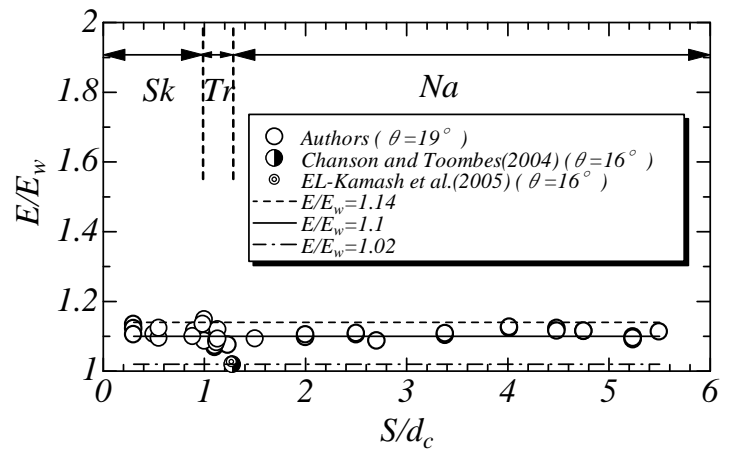

Sk:Skimming flow, Tr:Transition flow, Na:Nappe flow 図-14 $E / E_{w}$ とS/d $d_{c}$ 関係

$4.0<S / d_{c} \leqq 5.5$ のnappe flow 場合, $S / d_{c}$ の増加に伴い流 下寸るナップの流速が大きくなり，測定断面のE/d や大きくなったためであろうと考えられる.

図-14に空気混入流のエネルギー水頭 $E$ と clear waterの エネルギー水頭 $E_{w}$ との比を示寸．ここに， $E_{w}$ はclear waterのエネルギー水頭であり，(8)式と(13)式で $C_{p}=1$, $C_{v}=1$ とおいた(14)式と(15)式で示される.

$$
\begin{gathered}
E_{w}=d_{w}+\frac{V_{w}{ }^{2}}{2 g} \\
E_{w}=d_{w} \cos \theta+\frac{V_{w}{ }^{2}}{2 g}
\end{gathered}
$$

図-14に示されるように, $\theta=19^{\circ}$ の平衡状態における0.5 $\leqq S / d_{c} \leqq 5.5$ こおけるE/ $E_{w}$ の值は1.02〜1.14である.

\section{7. まとめ}

水路傾斜角度 $\theta=19^{\circ}$ におけるskimming flow, transition flow，およびnappe flowの空気混入流の内部特性につい て検討した結果を以下に要約して示す.

- 空気混入率分布および流速分布からskimming flow, transition flow，およびnappe flowを特徵づけることが できた.

- $0.3<S / d_{c}<3.0$ の場合, 断面平均空気混入率 $C_{m}$ は $S / d_{c}$ の 増加に伴い大きくなる．また， $3.0 \leqq S / d_{c} \leqq 5.5$ の nappe flowの場合, $C_{m}$ の值は一定值に近づく.

- skimming flowとtransition flowの場合, 流速分布は 1/N乗則で近似できる. また， nappe flowの場合，流 速は一様分布に近くなる.

- 空気混入流の断面平均流速 $V_{\text {ave }}$ とclear water depth $d_{w}$ から求められる平均流速 $V_{w}$ との関係は $V_{a v e} \fallingdotseq 1.04 V_{w}$ である.

・ transition flowとnappe flowの空気混入流のエネルギー 水頭は(8)式で評価されることを提示した.

- 空気混入流のエネルギー水頭 $E / d_{c}$ を図-12に示した.
- 補正係数 $C_{p}$ と $C_{v}$ の物理的解釈を示し, $C_{p}$ と $C_{v}$ の值を 図-9,10に示した.

- 空気混入流のエネルギー水頭Eとclear water depthか ら求められるエネルギー水頭 $E_{w}$ との関係を図-14に 示しE/ $E_{w} \fallingdotseq 1.1$ である.

謝辞: 著者の一人（高橋正行）は本研究の一部に科学研 究費補助金 若手研究Bの助成を受けた。ここに記して 謝意を表します。

\section{参考文献}

1) Ohtsu, I. and Yasuda, Y.: "Characteristics of flow conditions on stepped channels", Proc. the $27^{\text {th }}$ IAHR Cong., IAHR, Theme D, San Francisco, USA, pp.583-588, 1997.

2) Ohtsu, I., Yasuda, T., and Takahashi, M.: "Flow characteristics of skimming flows in stepped channels”, J. Hydraul. Engng., ASCE, Vol.130, No.9, pp.860-869, 2004.

3) Ohtsu, I., Yasuda, Y., and Takahashi, M.: Discussion of "Onset of skimming flow on stepped spillways", J. Hydraul. Engng, ASCE, Vol.127, No.6, pp.522-524, 2001.

4) Boes, R.M. and Hager, W.H.:” Two-phase flow characteristics of stepped spillways”, J. Hydr. Engrg., ASCE, Vol.129, No.9, pp.661 $-670,2003$.

5) Chanson, H. and Toombes, L.: "Hydraulics of stepped chutes: The transition flow”, J. Hydraul. Res., IAHR, Vol.42, No.1, pp.43-54, 2004.

6) EL-Kamash, M.K., Loewen, M.R., and Rajaratnam, N.: "An experimental investigation of jet flow on a stepped chute", $J$. Hydraul. Res., IAHR, Vol.43, No.1, pp.31-43, 2005.

7) Ohtsu, I., Yasuda, Y., and Takahashi, M.: "Energy head of aerated flows in stepped channels", Proc. the $31^{\text {st }}$ IAHR Cong, IAHR, Seoul, Korea, pp.2890-2899, 2005.

8) Chanson, H.: "Air-water flow measurements with intrusive phasedetection?”, J. Hydraul. Engng, ASCE, Vol.128, No.3, pp.252-255, 2002.

9) 高橋正行, 安田陽一, 大津岩夫：“階段状水路における空気 混入射流の特性に対するレイノルズ数の影響”，水工学論文 集，土木学会，50巻，pp.871-876, 2006.

10) Chanson, H., The hydraulics of stepped chutes and spillways, Balkema, Lisse, The Netherlands, 2001.

11) Chanson, $\mathrm{H}$ and Toombes, L.: "Air-water flows down stepped chutes: turbulence and flow structure observations", Int. J. Multiphase Flow, Vol.28, pp.1731-1761, 2002.

12)高橋正行, 安田陽一, 大津岩夫：“階段状水路における射 流のエネルギー”，水工学論文集，土木学会，第48巻， pp.871-876, 2004.

(2007. 9. 30受付) 